\title{
Análise crítica sobre a evolução das normas éticas para a utilização das técnicas de reprodução assistida no Brasil
}

\author{
Critical analysis on the evolution of ethical norms \\ for the use of assisted reproduction techniques in Brazil
}

Tatiana Henriques Leite ${ }^{1}$

${ }^{1}$ Programa de PósGraduação em Saúde Coletiva, Instituto de Medicina Social, Universidade Estadual do Rio de Janeiro. R. São Francisco Xavier 524/bl E/7º, Maracanã. 20550-013 Rio de Janeiro RJ Brasil. henriques.tatiana@ gmail.com

\begin{abstract}
The Federal Medical Council (FMC) published FMC Resolution No. 1,358/1992 with the aim of adopting ethical standards for the use of Assisted Reproduction Techniques (ART). This resolution was updated in 2010 (CFM No. 1957/2010), in 2013 (CFM No. 2,013/13) and the last update was in 2015 (CFM No. 2.121/2015). The scope of this article is to conduct a critical analysis of the evolution of the ethical norms proposed by FMC for the use of ART in Brazil. A documentary analysis of the text of the four published Resolutions was carried out, in which the ethical standards for the use of ART were described. It was observed that the resolution evolved in relation to the rights of homosexuals, adopted more permissive measures regarding cryopreservation, donation of gametes and embryos and uteruses on loan and lastly authorized some procedures in $A R T$ such as postmortem reproduction, donation and shared gestation. From 2013 onwards the resolution gained a liberal character being updated in terms of clinical practice. For the next updates it would be interesting to include procedures in ART not previously addressed such as nuclear and cytoplasmic transfer. The update frequency (every two years) should be kept to the ethical standards enabling the ART to continue evolving together with the advancement of science.
\end{abstract}

Key words Bioethics, Assisted reproduction techniques
Resumo O Conselho Federal de Medicina (CFM) publicou em 1992 a resolução CFM no 1.358/1992 com o objetivo de adotar normas éticas para utilização das técnicas de Reprodução Assistida (TRA). Esta resolução foi atualizada em 2010 (CFM no 1.957/2010), em 2013 (CFM No 2.013/13) e teve sua última atualização 2015 (CFM no 2.121/2015). O objetivo desse artigo é fazer uma análise crítica sobre a evolução das normas éticas propostas pelo CFM para a utilização de TRA no Brasil. Foi realizada uma análise documental do texto das quatro Resoluções publicadas onde estão descritas as normas éticas para utilização das TRA. Foi observado que a resolução evoluiu em relação aos direitos dos homossexuais, adotou medidas mais permissivas em relação a criopreservação, doação de gametas e embriões e cessão de útero e por fim autorizou alguns procedimentos em TRA como a reprodução post mortem, doação e gestação compartilhada. A partir de 2013 a resolução ganhou um caráter liberal estando atualizada com a prática clínica. Para as próximas atualizações seria interessante incluir procedimentos em TRA os quais não foram abordados como a transferência nuclear e citoplasmática. A frequência de atualização (a cada dois anos) deve ser mantida para as normas éticas que norteiam a TRA continuar evoluindo juntamente com o avanço da ciência.

Palavras-chave Bioética, Técnicas reprodutivas assistidas 


\section{Introdução}

Em 1978, nasceu na Inglaterra, Louise Brown, o primeiro bebê gerado através do procedimento de fertilização in vitro (FIV $)^{1}$. Este foi um marco importante para o surgimento de uma nova área na medicina chamado hoje de Reprodução Humana Assistida. São consideradas Técnicas de Reprodução Assistida (TRA) todos os procedimentos clínicos e laboratoriais que visam obter uma gestação, substituindo ou facilitando etapas deficientes do processo reprodutivo natural.

No Brasil, o primeiro bebê gerado por FIV data de 1984, após várias tentativas malsucedidas em anos anteriores ${ }^{2}$. O conhecimento sobre a disponibilidade das TRA ocorreu de forma rápida no Brasil devido ao grande sensacionalismo midiático que houve na época. Inúmeras manchetes de jornais, revistas e televisão dedicaram matérias inteiras ao tema. Devido à popularização do conhecimento sobre o assunto, assim como o crescente aumento do uso de TRA no Brasil, começaram a surgir diversos conflitos éticos, antes impossíveis com a reprodução natural. Os principais conflitos discutidos à época e nos dias de hoje dizem respeito à manipulação, criopreservação (congelamento de gametas e embriões ), doação e descarte de gametas e embriões, cessão de útero ("barriga de aluguel"), sexagem embrionária (técnicas de seleção do sexo do embrião), redução embrionária (procedimento de retirada de embriões do útero materno geralmente utilizado com o objetivo de evitar gestações múltiplas), reprodução post mortem (quando ocorre utilização de gametas previamente estocados ou embriões de uma pessoa falecida), e mais recentemente, o direito de casais homoafetivos à reprodução assistida ${ }^{2-4}$.

Apesar da ampla divulgação e conhecimento das TRA por parte da população, a regulamentação desses procedimentos no Brasil não teve a mesma velocidade. Muito se deve ao número restrito de profissionais e clínicas que eram e são capacitados a utilizar TRA no tratamento da infertilidade conjugal, ao acesso restrito desses procedimentos devido ao alto custo e a inexistência/dificuldade de disponibilidade da tecnologia através do Sistema Único de Saúde (SUS). Ainda assim, a regulamentação do uso de TRA é necessária para impedir o avanço da tecnologia de forma indiscriminada corrompendo preceitos morais da sociedade, assegurar os profissionais de saúde que trabalham na área de que os procedimentos realizados têm um respaldo na lei e na ética profissional vigente e também para garantir efetividade e qualidade dos tratamentos oferecidos aos pacientes.

No Brasil, já existiram diversos projetos de lei na tentativa de regulamentar a reprodução assistida. O primeiro foi proposto em 1993, o segundo em 1997, o terceiro em $1999^{5}$. Nenhum desses projetos conseguiu aprovação. Atualmente, existem cinco projetos de lei para regulamentação da reprodução assistida (PL 1135/2003; PL 1184/2003; PL 2061/2003, PL 4892/2012, PL-115/2015). Todos estão tramitando na Câmara dos Deputados ${ }^{6}$.

$\mathrm{Na}$ falta de uma regulamentação legislativa, o Conselho Federal de Medicina (CFM) publicou em 1992 a resolução CFM no 1.358/1992 com o objetivo de adotar normas éticas para utilização das TRA. Esta resolução foi atualizada em 2010 (CFM no 1.957/2010), em 2013 (CFM No 2.013/13) e teve sua última atualização em 2015 (CFM no 2.121/2015), sempre revogando a anterior $^{7-10}$.

Dessa forma, o objetivo desse artigo é fazer uma análise crítica sobre a evolução das normas éticas propostas pelo Conselho Federal de Medicina para a utilização de TRA no Brasil, no período de 1992 a 2015.

\section{Método}

Para alcançar o objetivo, foi realizada uma análise documental do texto das quatro Resoluções publicadas pelo Conselho Federal de Medicina, na qual são estabelecidas as normas éticas da utilização das TRA.

A escolha do método deu-se por este ser o mais apropriado ao objetivo proposto, podendo acrescentar a dimensão do tempo/contexto à compreensão do social. Além disso, a análise documental favorece a observação do processo de maturação ou de evolução de indivíduos, grupos, conceitos, conhecimentos, comportamentos, mentalidades, práticas, entre outros ${ }^{11}$.

\section{Resultado}

As resoluções foram analisadas de acordo com algumas categorias pré-definidas de temas: princípios gerais, pacientes-alvo das técnicas de TRA, doação de gametas e embriões, criopreservação de gametas e embriões, diagnóstico genético pré -implantacional de embriões, doação temporária de útero, e por fim, reprodução post-mortem.

Nos Quadros 1, 2 e 3, pode ser observado com maiores detalhes o texto original das resoluções 
Quadro 1. Comparação da resolução que regulariza TRA no Brasil nos anos de 1992, 2010, 2013 e 2015 para os quesitos "Princípios gerais" e "Pacientes alvo de TRA

\begin{tabular}{|c|c|c|c|c|}
\hline & 1992 & 2010 & 2013 & 2015 \\
\hline \multicolumn{5}{|c|}{ Princípios gerais } \\
\hline $\begin{array}{l}\text { Termo de } \\
\text { consentimento }\end{array}$ & \multicolumn{4}{|l|}{ Pacientes e doadores } \\
\hline Seleção de sexo & \multicolumn{4}{|c|}{ Proibido. (exceções são previstas) } \\
\hline $\begin{array}{l}\text { Idade máxima } \\
\text { da mulher } \\
\text { receptora }\end{array}$ & \multicolumn{2}{|l|}{ Sem limitação } & 50 anos & $\begin{array}{l}50 \text { anos (podem ocorrer } \\
\text { exceções a critério do } \\
\text { médico responsável) }\end{array}$ \\
\hline $\begin{array}{l}\text { Transferência } \\
\text { embrionária }\end{array}$ & $\begin{array}{l}\text { No máximo } 4 \text { embriões } \\
\text { sem restrições por idade }\end{array}$ & $\begin{array}{l}\text { No máximo } 4 \\
\text { embriões com } \\
\text { restrições por } \\
\text { idade }\end{array}$ & \multicolumn{2}{|c|}{$\begin{array}{l}\text { No máximo } 4 \text { embriões com restrições por } \\
\text { idade. Em casos de doação, a idade da doadora } \\
\text { define o número de embriões a serem } \\
\text { transferidos para a receptora }\end{array}$} \\
\hline Redução fetal & \multicolumn{4}{|l|}{ Proibido } \\
\hline \multicolumn{5}{|c|}{ Pacientes-alvo das técnicas de Reprodução Assistida } \\
\hline Público alvo & Mulheres & \multicolumn{3}{|c|}{ Todas as pessoas capazes } \\
\hline Estado civil & $\begin{array}{l}\text { Estando casada ou } \\
\text { em união estável, será } \\
\text { necessária a aprovação } \\
\text { do cônjuge ou do } \\
\text { companheiro, após } \\
\text { processo semelhante de } \\
\text { consentimento informado. }\end{array}$ & \multicolumn{3}{|c|}{ Não mencionado } \\
\hline Homoafetivos & \multicolumn{2}{|l|}{ Não mencionado } & \multicolumn{2}{|c|}{$\begin{array}{l}\text { É permitido o uso das técnicas de RA para } \\
\text { relacionamentos homoafetivos e pessoas } \\
\text { solteiras, respeitado o direito da objeção de } \\
\text { consciência do médico. }\end{array}$} \\
\hline $\begin{array}{l}\text { Homoafetivos } \\
\text { femininos }\end{array}$ & \multicolumn{3}{|l|}{ Não mencionado } & $\begin{array}{l}\text { É permitida a gestação } \\
\text { compartilhada em } \\
\text { união homoafetiva } \\
\text { feminina em que não } \\
\text { exista infertilidade. }\end{array}$ \\
\hline
\end{tabular}

dos anos de 1992, 2010, 2013, 2015. Para facilitar a comparação, os trechos em negrito identificam as mudanças referentes à resolução anterior.

\section{Discussão}

\section{Contexto e principais mudanças das resoluções ao longo do tempo}

A resolução de 1992 teve um contexto social bastante interessante. Ela ocorreu 8 anos depois do nascimento do primeiro "bebê de proveta" no Brasil. Durante esse período, não havia qualquer regulamentação das TRA e, inclusive, eram realizados dentro dos laboratórios brasileiros alguns procedimentos os quais futuramente seriam proibidos na Resolução de 1992 assim como nas seguintes, como por exemplo, a sexagem embrionária ${ }^{2,12}$.
O apelo midiático em torno da temática e a falta de legislação específica podem ser apontados como fatores essenciais para pressionar o CFM a publicar uma recomendação sobre as normas éticas para a prática da reprodução assistida. Na década de 1990, jornais e revistas de grande circulação no país fizeram grandes reportagens explorando as questões éticas que surgiram com a reprodução assistida. A possibilidade de clonagem humana, descarte de embriões humanos, início da vida, seleção de sexo e eugenia foram assuntos explorados pelo jornalismo ${ }^{2}$. Apesar da grande visibilidade, questões éticas mais palpáveis foram deixadas em segundo plano pela população nesse momento. No entanto, a exibição de uma novela intitulada "barriga de aluguel" entre os anos de 1990 e 1991 trouxe à tona uma discussão popular sobre o assunto. Em virtude desse acontecimento, em 1992, o CFM publicou a resolução CFM no $1.358 / 1992^{7}$. 
Quadro 2. Comparação da resolução que regulariza TRA no Brasil nos anos de 1992, 2010, 2013 e 2015 para os quesitos "Doação e criopreservação de gametas e embriões".

\begin{tabular}{|c|c|c|c|c|}
\hline & 1992 & 2010 & 2013 & 2015 \\
\hline \multicolumn{5}{|c|}{ Doação de gametas e embriões } \\
\hline Comercialização & \multicolumn{4}{|c|}{ Sem caráter lucrativo ou comercial } \\
\hline Identificação & \multicolumn{4}{|c|}{ anônima para doadores e receptores } \\
\hline $\begin{array}{l}\text { Idade limite } \\
\text { para a doação de } \\
\text { gametas }\end{array}$ & \multicolumn{2}{|l|}{ Não mencionado } & \multicolumn{2}{|c|}{$\begin{array}{l}\text { A idade limite para a doação de gametas } \\
\text { é de } 35 \text { anos para a mulher e } 50 \text { anos } \\
\text { para o homem }\end{array}$} \\
\hline Registros & $\begin{array}{l}\text { Na região de } \\
\text { localização da } \\
\text { unidade, o registro } \\
\text { das gestações evitará } \\
\text { que um doador tenha } \\
\text { produzido mais de } 2 \\
\text { (duas) gestações, de } \\
\text { sexos diferentes, numa } \\
\text { área de um milhão de } \\
\text { habitantes. }\end{array}$ & $\begin{array}{l}\text { As clínicas, centros ou } \\
\text { serviços que empregam } \\
\text { a doação devem manter, } \\
\text { de forma permanente, } \\
\text { um registro de dados } \\
\text { clínicos de caráter geral, } \\
\text { características fenotípicas } \\
\text { e uma amostra de material } \\
\text { celular dos doadores. Na } \\
\text { região de localização da } \\
\text { unidade, o registro dos } \\
\text { nascimentos evitará que } \\
\text { um(a) doador(a) venha a } \\
\text { produzir mais do que uma } \\
\text { gestação de criança de sexo } \\
\text { diferente numa área de um } \\
\text { milhão de habitantes. }\end{array}$ & \multicolumn{2}{|c|}{$\begin{array}{l}\text { As clínicas, centros ou serviços que } \\
\text { empregam a doação devem manter, de } \\
\text { forma permanente, um registro de dados } \\
\text { clínicos de caráter geral, características } \\
\text { fenotípicas e uma amostra de material } \\
\text { celular dos doadores, de acordo com } \\
\text { a legislação vigente. Na região de } \\
\text { localização da unidade, o registro dos } \\
\text { nascimentos evitará que um(a) doador(a) } \\
\text { tenha produzido mais de duas gestações } \\
\text { de crianças de sexos diferentes, numa área } \\
\text { de um milhão de habitantes. }\end{array}$} \\
\hline $\begin{array}{l}\text { Doação } \\
\text { compartilhada }\end{array}$ & \multicolumn{2}{|l|}{ Não mencionado } & \multicolumn{2}{|l|}{ Permitido } \\
\hline \multicolumn{5}{|c|}{ Criopreservação de gametas e embriões } \\
\hline Criopreservação & $\begin{array}{l}\text { As clínicas, centros } \\
\text { ou serviços podem } \\
\text { criopreservar } \\
\text { espermatozoides, } \\
\text { óvulos e pré- } \\
\text { embriões. Embriões } \\
\text { excedentes devem } \\
\text { ser criopreservados, } \\
\text { não podendo ser } \\
\text { descartados ou } \\
\text { destruídos. } \\
\end{array}$ & $\begin{array}{l}\text { As clínicas, centros } \\
\text { ou serviços podem } \\
\text { criopreservar } \\
\text { espermatozoides, óvulos e } \\
\text { embriões. Do número total } \\
\text { de embriões produzidos } \\
\text { em laboratório, os } \\
\text { excedentes viáveis, serão } \\
\text { criopreservados. }\end{array}$ & \multicolumn{2}{|c|}{$\begin{array}{l}\text { As clínicas, centros ou serviços podem } \\
\text { criopreservar espermatozoides, óvulos } \\
\text { e embriões e tecidos gonádicos. } \\
\text { Embriões excedentes viáveis devem ser } \\
\text { criopreservados. }\end{array}$} \\
\hline $\begin{array}{l}\text { Destino dos } \\
\text { embriões }\end{array}$ & \multicolumn{4}{|c|}{$\begin{array}{l}\text { No momento da criopreservação, os cônjuges ou companheiros devem expressar sua vontade, } \\
\text { por escrito, quanto ao destino que será dado aos pré-embriões criopreservados, em caso de } \\
\text { divórcio, doenças graves ou de falecimento de um deles ou de ambos, e quando desejam doá-los. }\end{array}$} \\
\hline Descarte & $\begin{array}{l}\text { Embrião não pode } \\
\text { ser descartado ou } \\
\text { destruído }\end{array}$ & $\begin{array}{l}\text { Os embriões criopreservado } \\
\text { (cinco) anos poderão ser } \\
\text { descartados se esta for a von } \\
\text { e não apenas para pesquisas } \\
\text { conforme previsto na Lei de }\end{array}$ & $\begin{array}{l}\text { os com mais de } 5 \\
\text { de células-tronco, } \\
\text { Biossegurança. }\end{array}$ & $\begin{array}{l}\text { Os embriões } \\
\text { criopreservados } \\
\text { com mais de cinco } \\
\text { anos poderão ser } \\
\text { descartados se } \\
\text { esta for a vontade } \\
\text { dos pacientes. A } \\
\text { utilização dos } \\
\text { embriões em } \\
\text { pesquisas de } \\
\text { células-tronco } \\
\text { não é obrigatória, } \\
\text { conforme } \\
\text { previsto na Lei de } \\
\text { Biossegurança. }\end{array}$ \\
\hline
\end{tabular}


Quadro 3. Comparação da resolução que regulariza TRA no Brasil nos anos de 1992, 2010, 2013 e 2015 para os quesitos " diagnóstico genético pré-implantacional", "Doação temporária de útero" e "Reprodução Assistida Postmortem".

\begin{tabular}{|c|c|c|c|c|}
\hline & 1992 & 2010 & 2013 & 2015 \\
\hline \multicolumn{5}{|c|}{ Diagnóstico genético pré-implantacional de embriões } \\
\hline $\begin{array}{l}\text { Finalidade } \\
\text { diagnóstica do } \\
\text { PGD }\end{array}$ & \multicolumn{2}{|c|}{$\begin{array}{l}\text { Toda intervenção sobre pré- } \\
\text { embriões “in vitro", com fins } \\
\text { diagnósticos, não poderá ter outra } \\
\text { finalidade que a avaliação de sua } \\
\text { viabilidade ou detecção de doenças } \\
\text { hereditárias, sendo obrigatório o } \\
\text { consentimento informado do casal. }\end{array}$} & $\begin{array}{l}\text { As técnicas de RA } \\
\text { podem ser utilizadas } \\
\text { acopladas à seleção de } \\
\text { embriões submetidos } \\
\text { ao diagnóstico de } \\
\text { alterações genéticas } \\
\text { causadoras de doenças. }\end{array}$ & $\begin{array}{l}\text { As técnicas de RA podem ser } \\
\text { utilizadas aplicadas à seleção } \\
\text { de embriões submetidos ao } \\
\text { diagnóstico de alterações } \\
\text { genéticas causadoras de } \\
\text { doenças - podendo nesses } \\
\text { casos serem doados para } \\
\text { pesquisa ou descartados. }\end{array}$ \\
\hline $\begin{array}{l}\text { Finalidade } \\
\text { terapêutica do } \\
\text { PGD }\end{array}$ & \multicolumn{2}{|c|}{$\begin{array}{l}\text { Toda intervenção com fins } \\
\text { terapêuticos, sobre pré-embriões } \\
\text { “in vitro”, não terá outra finalidade } \\
\text { que tratar uma doença ou impedir } \\
\text { sua transmissão, com garantias reais } \\
\text { de sucesso, sendo obrigatório o } \\
\text { consentimento informado do casal. }\end{array}$} & $\begin{array}{l}\text { As técnicas de RA } \\
\text { também podem ser } \\
\text { utilizadas para tipagem } \\
\text { do sistema HLA do } \\
\text { embrião, com o intuito } \\
\text { de seleção de embriões } \\
\text { HLA-compatíveis com } \\
\text { algum filho(a) do casal } \\
\text { já afetado por doença, } \\
\text { doença está que tenha } \\
\text { como modalidade de } \\
\text { tratamento efetivo o } \\
\text { transplante de células- } \\
\text { tronco ou de órgãos. }\end{array}$ & $\begin{array}{l}\text { As técnicas de RA também } \\
\text { podem ser utilizadas para } \\
\text { tipagem do sistema HLA } \\
\text { do embrião, no intuito } \\
\text { de selecionar embriões } \\
\text { HLA-compatíveis com } \\
\text { algum(a) filho(a) do casal } \\
\text { já afetado pela doença e } \\
\text { cujo tratamento efetivo seja } \\
\text { o transplante de células- } \\
\text { tronco, de acordo com a } \\
\text { legislação vigente. }\end{array}$ \\
\hline \multicolumn{5}{|c|}{ Doação temporária de útero } \\
\hline Cessão de útero & \multicolumn{2}{|l|}{ Permitido } & \multicolumn{2}{|c|}{ Permitido, inclusive para casais homoafetivos } \\
\hline $\begin{array}{l}\text { Grau de } \\
\text { parentesco }\end{array}$ & \multicolumn{2}{|c|}{$\begin{array}{l}\text { Até segundo grau da doadora } \\
\text { genética }\end{array}$} & \multicolumn{2}{|c|}{$\begin{array}{l}\text { Até quarto grau de um dos parceiros que compõem } \\
\text { o casal }\end{array}$} \\
\hline Comercialização & \multicolumn{4}{|c|}{ Sem caráter lucrativo ou comercial } \\
\hline $\begin{array}{l}\text { Documentação } \\
\text { exigida }\end{array}$ & \multicolumn{2}{|c|}{ Não mencionado } & \multicolumn{2}{|c|}{$\begin{array}{l}\text { Termo de Consentimento Informado assinado pelos } \\
\text { pacientes (pais genéticos) e pela doadora temporária } \\
\text { do útero, relatório médico atestando capacidade } \\
\text { psicológica da doadora de útero, descrição } \\
\text { pormenorizada do caso clínico, contrato dos pais } \\
\text { genéticos com a doadora de útero estabelecendo } \\
\text { claramente a filiação da criança, questões referente } \\
\text { ao custeio de despesas médicas e registro civil da } \\
\text { criança entre outros e se a doadora de útero for } \\
\text { casada ou viver em união estável, apresentar por } \\
\text { escrito aprovação do cônjuge. }\end{array}$} \\
\hline \multicolumn{5}{|c|}{ Reprodução Assistida Post-Mortem } \\
\hline $\begin{array}{l}\text { Reprodução } \\
\text { assistida post- } \\
\text { mortem }\end{array}$ & $\begin{array}{l}\text { Não } \\
\text { mencionado }\end{array}$ & $\begin{array}{l}\text { Não constitui ilícito } \\
\text { ético a reprodução } \\
\text { assistida post mortem } \\
\text { desde que haja } \\
\text { autorização prévia } \\
\text { específica do(a) } \\
\text { falecido(a) para o uso } \\
\text { do material biológico } \\
\text { criopreservado, } \\
\text { de acordo com a } \\
\text { legislação vigente. }\end{array}$ & $\begin{array}{l}\text { É possível desde } \\
\text { que haja autorização } \\
\text { prévia específica do(a) } \\
\text { falecido(a) para o uso } \\
\text { do material biológico } \\
\text { criopreservado, de } \\
\text { acordo com a legislação } \\
\text { vigente. }\end{array}$ & $\begin{array}{l}\text { É permitida a reprodução } \\
\text { assistida post-mortem desde } \\
\text { que haja autorização prévia } \\
\text { específica do(a) falecido(a) } \\
\text { para o uso do material } \\
\text { biológico criopreservado, } \\
\text { de acordo com a legislação } \\
\text { vigente. }\end{array}$ \\
\hline $\begin{array}{l}\text { Como tratar } \\
\text { exceções }\end{array}$ & \multicolumn{2}{|c|}{ Não mencionado } & \multicolumn{2}{|c|}{$\begin{array}{l}\text { Casos de exceção, não previstos nesta resolução, } \\
\text { dependerão da autorização do Conselho Regional de } \\
\text { Medicina. }\end{array}$} \\
\hline
\end{tabular}


A Resolução de 1992 foi baseada no Warnock Report de 1984, um guideline que tinha por objetivo regulamentar a prática da fertilização in vitro nos Países do Reino Unido 5 . Foi uma resolução bastante tímida e representava basicamente o desejo dos médicos e outros profissionais de saúde que trabalhavam na área. Resumidamente, essa resolução proibiu a redução embrionária, a seleção de sexo, a transferência de mais de 4 embriões por ciclo (tentativa) e a destruição e comercialização de gametas e embriões. Por outro lado, permitiu a prática de congelamento e a realização de diagnóstico genético pré-implantacional $(\mathrm{PGD})^{7}$. Foi omissa em todos os outros aspectos não mencionados, e por isso é considerada conservadora, ainda que para os padrões da época. Esta resolução ficou vigente durante 18 anos até ser substituída pela resolução de 2010.

O contexto social da resolução de 2010 foi bastante diferente da primeira. Essa resolução trouxe muitas transformações de uma única vez, e não foi por acaso. Após 18 anos em vigor, a resolução de 92 estava tão defasada que não condizia com a prática clínica. Além disso, os aspectos em que a resolução era omissa, dava margens a diferentes entendimentos entre os profissionais que trabalham nesse campo. Uns acreditavam que a omissão, por exemplo, da reprodução assistida post-mortem não significava ato antiético, já que a resolução não condenava expressamente a prática. Outros acreditavam que pelo fato desse aspecto não ter sido mencionado, não poderia ser realizado.

As principais alterações incorporadas com a resolução de 2010 foram: a transferência embrionária limitada por faixa etária da mulher (até 35 anos - 2 embriões; entre 36 e 39 anos - 3 embriões e mais de 40 anos-máximo 4 embriões), a não exigência de estado civil e sexo específico para ser considerado candidato a TRA, a possibilidade de descarte de embrião e, por fim, a regularização da reprodução assistida post mortem. Essa resolução inovou por abrir o debate sobre a utilização das TRA por pessoas solteiras e casais homoafetivos ${ }^{8}$. No entanto, foi considerada conservadora por abordar esse e outros temas polêmicos de uma maneira discreta. Apesar do pouco tempo decorrido desde a publicação da resolução de 2010, em 2013 ela foi novamente atualizada.

Três aspectos principais marcam o contexto da resolução de 2013. O primeiro foi a necessidade de reforçar a tendência de atualizações frequentes para que o documento não se tornasse obsoleto, como aconteceu com a resolução de 1992. O segundo foi assegurar de maneira clara e definitiva o direito de pessoas solteiras e homossexuais a terem acesso às TRA. O terceiro aspecto foi a limitação da idade da mulher para gestar. Além dessas modificações, a resolução de 2013 também incorporou diversas alterações como: estipulação de idade limite para doação de gametas, previsão de criopreservação de tecido gonádico, alterações nas finalidades diagnósticas e terapêuticas do PGD, cessão de útero com documentação comprobatória e afrouxamento dos laços sanguíneos para a receptora do embrião e, por fim, a determinação de que todos os casos não previstos na resolução devem ser encaminhados para o Conselho Federal de Medicina9.

A resolução de 2013 foi muito criticada devido a limitação imposta às mulheres em relação $\mathrm{a}$ idade para gestar, mas também por ter sido omissa em determinados aspectos que estavam em ascensão na prática clínica. Com isso, a resolução de 2015 veio preencher essas lacunas. Em termos de inovação, é destaque a doação compartilhada de oócitos (procedimento que consiste na doação de metade dos oócitos de uma mulher para outra mulher mediante o custeio do tratamento da primeira), a permissão para gestação compartilhada (ocorre quando em um casal de mulheres uma doa os oócitos e a outra faz a gestação) entre casais homoafetivos feminino e, por fim, uma relativização da idade da mulher para gestar. Apesar de poucas inovações quando comparada com as outras resoluções, a atual recomendação (2015), abordou temas ainda não mencionados nas resoluções antecessoras. A doação compartilhada de oócito era um desejo antigo tanto dos pacientes quanto dos profissionais. Além disso, a resolução vigente veio garantir os direitos reprodutivos das mulheres em relacionamentos homoafetivos, até então não assegurados explicitamente. Por fim, foi mantido o limite de 50 anos de idade para mulheres gestar, mas devido à inúmeras discussões sobre o assunto, é possível que a questão idade seja avaliada caso a caso ${ }^{10}$.

\section{Princípios Gerais}

Não houve modificação no texto em relação à necessidade do termo de consentimento e à proibição da seleção de sexo e redução embrionária, ao longo das quatro resoluções avaliadas. O procedimento de redução embrionária é expressamente proibido em todas as resoluções. Em contrapartida, estratégias para diminuir a incidência de gravidezes gemelares têm sido adotadas. Um exemplo disso é a limitação do número de embriões transferidos de acordo com a idade da mu- 
lher. Essa estratégia tem funcionado na prática e tem sido bem aceita por profissionais e pacientes para resguardar a mulher e os fetos em formação. Ainda assim, discutir redução embrionária em reprodução assistida é um assunto bastante polêmico e diversas vertentes de ideologias norteiam a proibição. A primeira vertente é a religiosa. No Brasil, um dos fundamentos para a proibição e criminalização do aborto é de caráter religioso. Assim, por extensão, a redução embrionária recebe o mesmo entendimento e proibição. A segunda vertente é que a gravidez múltipla pode ser evitada ou ter a incidência diminuída com as TRA. Dessa forma, a redução embrionária é considerada uma intervenção iatrogênica podendo causar dano à mulher e aos outros fetos em desenvolvimento. A última vertente é relacionada a percepção dos profissionais de saúde que trabalham na área. Muitos se dizem contra a redução embrionária por entender que ao trabalhar com reprodução assistida o seu objetivo como profissional é gerar vida.

Com a falta de possibilidade de fazer redução embrionária e com a crescente preocupação em garantir a segurança da mulher, a prevenção de gravidez múltipla através do número de embriões transferidos e faixa etária poderia ser melhorado. Aspectos relacionados ao embrião e ao caso clínico poderiam ser considerados como, por exemplo, a qualidade embrionária, estágio de desenvolvimento embrionário no momento da transferência (dia 3 ou blastocisto) e número de tentativas falhas em ciclos anteriores. Todos esses critérios são utilizados pela American Society for Reproductive Medicine (ASRM) para determinar o número de embriões a ser transferidos ${ }^{13}$.

Em relação aos pacientes alvo das TRA houve muitas mudanças entre as quatro resoluções. Em 1992 o público alvo para utilizar TRA era a mulher casada ou em união estável. A partir de 2010 o texto sofre modificações e todas as pessoas capazes passaram a ter o direito a utilizar as técnicas. O texto "toda pessoa capaz" é percebido de forma bastante ampla, significando que todas as pessoas com autonomia para exercer seus direitos e deveres, sem distinção de sexo, raça, condição socioeconômica, estado civil e orientação sexual pode fazer uso de TRA. No entanto, para deixar o texto ainda mais claro nas resoluções seguintes (2013 e 2015), o direito dos homossexuais e pessoas solteiras foi explicitado. Apesar de todos os direitos garantidos aos homossexuais, somente com a resolução de 2015 um desejo antigo entre as homossexuais femininas foi atendido: a gestação compartilhada. A resolução de 2015 tem um entendimento vanguardista a respeito dos casais homoafetivos femininos. Essa resolução permite a gestação compartilhada entre duas mulheres, até então proibida pela cláusula de doação anônima de gametas e embriões. Essa resolução entende que a gestação compartilhada não fere o princípio da doação anônima, pois percebe os casais homossexuais femininos como de fato um casal. Então, assim como há combinação de material genético entre um casal heterossexual, a gestação compartilhada entre homossexuais femininas é a forma de viabilizar a "combinação" dessas mulheres.

No entanto, apesar da atitude liberal do CFM em relação aos homossexuais, a resolução de 2013 e a vigente (2015), dispõe que o médico tem direito de recusar realizar o tratamento nesses casos. Essa afirmação gera uma incompatibilidade com o que está previsto no Código de Ética Médica publicada pelo próprio CFM. O código dispõe A Medicina é uma profissão a serviço da saúde do ser humano e da coletividade e será exercida sem discriminação de nenhuma natureza ${ }^{14}$. Dessa forma, negar atendimento aos homossexuais devido, exclusivamente, a sua orientação sexual, caracteriza discriminação. No entanto, o mesmo código de ética médica também dispõe que é direito do médico Recusar-se a realizar atos médicos que, embora permitidos por lei, sejam contrários aos ditames de sua consciência ${ }^{14}$. Assim, o mesmo código de ética médica que expressa que a medicina deve ser exercida sem discriminação de nenhuma natureza também oferece suporte ético para os profissionais dessa categoria agir de forma discriminatória.

\section{Doação de gametas e embriões}

Em relação à doação de gametas e embriões, não houve alterações em relação à comercialização, garantida pela Constituição Federal, artigo 199, $4^{\text {o }}$ parágrafo ${ }^{15}$ e o anonimato dos doadores nas quatro resoluções analisadas. No entanto, os dois pilares que regem as doações devem ser analisados sob diversos pontos de vista.

$\mathrm{O}$ anonimato dos doadores oferece vantagem no sentido de facilitar o processo de doação de gametas devido falta de vínculo com os doadores. Por consequência problemas em relação à filiação da criança entre doadores e receptores também são evitados. No entanto, essa proibição, na prática clínica, torna muitas vezes o processo de doação bastante difícil já que não existe um excesso de gametas e embriões no mercado. Além disso, não existe incentivo para pessoas e casais com 
gametas e embriões excedentes fazerem doação para outras pessoas em situação semelhante. $\mathrm{O}$ Brasil é considerado bastante conservador nesse aspecto. Nos Estados Unidos, por exemplo, a comercialização de gametas e embriões é livre, pode ser feita por comunidades na internet, prevendo, inclusive, vários arranjos familiares. Ainda nesse país é comum remunerar o doador dos gametas ou embriões com quantias que dependem desde do material doado (espermatozoide, oócito ou embrião) até a qualidade desse material ${ }^{13,16}$.

Em relação ao anonimato, existem outras formas de conduzir essa questão. Nos Estados Unidos, o doador tem autonomia para escolher se ele deseja ou não ser identificado ${ }^{16,17}$. Na Suécia, toda doação é necessariamente identificada, não havendo possibilidade de ser feita de forma anônima ${ }^{18}$. O entendimento para tal "ousadia" vai muito além do desejo do doador e do receptor. Nesse país vigora a concepção que todo ser humano tem o direito de saber a sua ancestralidade, tornando a doação anônima de gametas e embriões ato inconcebível.

Apesar das dificuldades com as doações de gametas e embriões impostas por todas as resoluções, inclusive a vigente, não há como negar que a partir da resolução de 2013 a doação de oócitos foi facilitada através da doação compartilhada. Esse procedimento consiste na doação de metade dos oócitos de uma mulher para outra mulher mediante o custeio do tratamento da doadora. Essa doação ocorre de forma anônima entre os pacientes envolvidos e é orquestrada pela clínica que realiza o TRA.

No Brasil, a questão do anonimato entre doadores e receptores gera um paradoxo com as legislações vigente. A lei 8.069 que dispõe sobre o Estatuto da Criança e do Adolescente dispõe no artigo 27 que $O$ reconhecimento do estado de filiação é direito personalíssimo, indisponível e imprescritivel, podendo ser exercitado contra os pais ou seus herdeiros, sem qualquer restrição, observado o segredo de Justiça. Ainda na mesma lei, o artigo 48 , em relação a crianças adotadas, dispõe: $O$ adotado tem direito de conhecer sua origem biológica, bem como de obter acesso irrestrito ao processo no qual a medida foi aplicada e seus eventuais incidentes, após completar 18 (dezoito) anos. Dessa forma, a resolução, ao manter o caráter anônimo das doações como um dos princípios éticos que norteiam a prática, contradiz o que a lei do Estatuto da Criança e do Adolescente determina como legal ${ }^{19}$. A real necessidade do anonimato das doações deveria ser revista na próxima atualização das normas éticas que regem a reprodução assistida no Brasil. Diferente da prática de não comercialização a qual é prevista na constituição o anonimato é um critério estabelecido pela própria Resolução. Assim, outras possibilidades deveriam ser avaliadas como por exemplo a permissão de doação de gametas por membros da família (semelhante ao que acontece na cessão de útero).

Em relação à idade para doação, nas resoluções mais antigas (1992 e 2010) não havia restrição de idade para fazer doação de gametas. A partir de 2013 essa restrição foi feita tanto para homens (50 anos) quanto para mulheres (35 anos). Essa limitação é bastante bem-vinda, pois é consenso na literatura que gametas provenientes de homens e mulheres com idades superiores às mencionadas têm maior probabilidade de gerar embriões com anomalias genéticas ${ }^{20,21}$. Entretanto, a resolução de 2015, em vigor atualmente, não faz restrição à doação de embriões provenientes de doadores genéticos acima dessas faixas etárias. Esse quesito poderia ser abordado de maneira clara e objetiva na próxima atualização desse documento.

Todas as resoluções abordam ainda que as clínicas que realizam procedimento em TRA deveriam manter um registro do material genético doado. Na resolução de 1992 há uma preocupação que o doador não produza dois embriões de sexo diferentes em uma área de um milhão de habitantes. A partir de 2010, essa preocupação é mantida acrescida da manutenção de um registro sobre dados clínicos e características fenotípicas dos doadores. A crítica em fazer esses registros está relacionada a maneira descentralizada como isso é realizado. Ainda que as clínicas de reprodução assistida façam esse cadastramento, esse banco de dados não é unificado. Assim, uma pessoa pode fazer doação em várias clínicas diferentes sem que haja um controle sobre o número de embriões e bebês gerados desse progenitor. Um sistema de doação unificado poderia não só diminuir a probabilidade de possíveis casamentos consanguíneos como também explorar as doações de uma maneira mais efetiva em relação à oferta e procura.

\section{Doação temporária de útero}

A doação temporária de útero (ou cessão de útero) também sofreu uma grande evolução ao longo do tempo no Brasil. No entanto, alguns critérios não foram modificados: o caráter não-comercial do procedimento, garantida pela Constituição Federal, artigo 199, $4^{\circ}$ parágrafo $^{15}$ e 
a necessidade de parentesco da receptora do embrião com os doadores genéticos. Para viabilizar a cessão de útero, houve todo um trabalho para orquestrar o que era permitido e proibido na resolução em vigor, entretanto, esse fino ajuste nem sempre foi bem-sucedido. Por exemplo, com a resolução de 2010 era possível que homens solteiros e em relacionamentos homoafetivos utilizassem a cessão de útero para ter filhos biológicos. No entanto, a escolha da doadora do útero tinha que ser até o segundo grau de parentesco (mãe ou irmã) da doadora genética, ou seja, a mulher. Nesse caso específico, a doadora genética é anônima, pois os oócitos são conseguidos através de doação. Sendo assim, a resolução não indicava solução ética para esses casos.

Para não cometer o mesmo equívoco, a limitação da idade da mulher para gestar teve uma consequência direta nas regras de cessão do útero. Houve a necessidade de expandir o grau de parentesco de segundo grau para quarto grau (mãe, irmã, tia e prima), podendo incluir a família do casal envolvido no TRA, e não somente a da mulher. A expansão do grau de parentesco foi fundamental para viabilizar a cessão de útero. Sem essa modificação a probabilidade de encontrar alguém elegível na família seria praticamente nula.

Por fim, a partir de 2013, houve a necessidade de anexar ao prontuário dos pacientes alguns documentos comprobatórios relacionados a doação. Entre a documentação exigida está uma declaração do marido ou companheiro da mulher doadora de útero, se casada ou em união estável, aprovando a realização do procedimento. Tal fato fere diretamente a autonomia da mulher sobre seu corpo, constituindo um lapso retrógrado em uma resolução que vem mostrando uma evolução bastante liberal. A necessidade desse termo deveria ser revista na próxima atualização.

No Brasil, um dos grandes problemas dos pacientes que utilizam procedimento de cessão de útero é relacionado com a filiação. Isso ocorre, pois, a maternidade é presumida pela gestação, sendo mãe aquela que pariu a criança. Dessa forma, a mãe biológica não tem a maternidade presumida na maternidade. Juridicamente o processo de reconhecimento da filiação costumava ser bastante penoso para as famílias. Com a resolução de 2013 e 2015 a solução desse problema foi facilitada. Através de documentação comprobatória o Documento de nascido vivo (DNV) emitido pela maternidade pode ser realizado no nome da mãe biológica, porém é necessária uma liminar no sentido de determinar ao hospital a expedição da DNV em nome da verdadeira mãe.

\section{Criopreservação de gametas e embriões}

Em relação à Criopreservação de gametas e embriões, houve grande avanço desde 1992. Nesse primeiro momento, todos os embriões deveriam necessariamente ser criopreservados, sendo eles viáveis ou não. A partir de 2010, somente os excedentes viáveis teriam que ser criopreservados e, após 5 anos nesta condição, os progenitores passam a ter o poder de decidir o que fazer com esses embriões excedentes. Entre as opções disponíveis está a doação para outro paciente para pesquisa ou a destruição.

A possibilidade de destruição de embriões, de certa forma, abre uma grande discussão sobre a origem da vida humana. Sobre essa questão, existem três posicionamentos para tentar definir o momento exato em que a vida se inicia. A teoria mais conservadora entende que vida começa no momento da fertilização do oócito pelo espermatozoide ${ }^{22}$. Outra teoria, extrema em relação à primeira, afirma que o embrião é um conjunto de células e dessa forma não merece nenhuma diferença de tratamento que qualquer outro grupo celular. A ASRM tem uma ideia intermediária. Ela propõe que o embrião tem um status especial em relação a outros tecidos humanos, mas que não justifica ser visto e protegido como uma pessoa $^{23}$. Assim, com a permissão da destruição de embriões humanos, o CFM adota o posicionamento muito semelhante às ideologias da ASRM e do restante dos países desenvolvidos ${ }^{18}$.

\section{Diagnóstico genético pré-implantacional (PGD)}

Em relação ao PGD, uma grande e positiva mudança foi incorporada nas duas resoluções mais recentes. A partir de 2013 foi permitida a utilização do PGD para seleção de embrião HLA compativel com algum filho do casal afetado por doença que tenha como tratamento o transplante de célula-tronco ${ }^{9}$. Com o avanço da genética, a utilização do PGD é um assunto cada vez mais controverso. Muitos países com legislações ou guidelines mais conservadores para TRA, proíbem sua prática por acreditar que abre um precedente para a seleção de características específicas da pessoa, criando uma forma de eugenia ou seleção. Na China, o PGD foi utilizado durante muitos anos de forma indiscriminada para a seleção de embriões do sexo masculino. O déficit de meninas que deixaram de nascer foi tão grande que a prática foi proibida para qualquer finalidade $^{18}$. Para evitar problemas como o exempli- 
ficado, as consequências da seleção de determinadas características através do PGD devem ser analisadas cuidadosamente. $\mathrm{O}$ avanço da ciência é positivo na cura e na prevenção de doenças. No entanto, a seleção de embriões por caraterísticas fenotípicas, somente, deve ser limitado.

\section{Reprodução assistida post mortem}

A Reprodução assistida post mortem é permitida no Brasil desde 2010. É necessário que o cônjuge falecido tenha deixado uma declaração por escrito permitindo a utilização do seu material genético em caso de falecimento. Houve mudanças sutis no texto que regula o procedimento. Em 2010, a resolução apresenta um texto na negativa não constitui ilícito ético a reprodução assistida post mortem. Em 2013, o texto foi alterado para é possível desde que haja autorização prévia. Até, por fim, na resolução vigente, o texto foi modificado novamente para é permitido a reprodução post mortem...

A reprodução post mortem foi durante muito tempo discutida em termos das potencias consequências que poderiam gerar. Muitos acreditam que constitui ilícito ético gerar uma criança que já vai nascer sem um dos seus pais, entretanto, não há consenso a respeito ${ }^{3}$. Outro assunto bastante discutido em relação a esse procedimento específico é a questão da herança. Uma criança gerada após o falecimento de um de seus pais participaria da partilha da herança? O código civil brasileiro, por exemplo, não prevê essa possibilidade. O artigo 1.798 do código civil dispõe Legitimam-se a suceder as pessoas nascidas ou já concebidas no momento da abertura da sucessão. Assim, herdeiros nascidos via reprodução assistida post mortem não têm direito sucessório garantido ${ }^{24}$. Por fim, em relação a filiação, o código civil prevê o reconhecimento da paternidade no caso de reprodução post mortem (artigo 1597, inciso III e IV $)^{24}$. O reconhecimento da maternidade ocorre da maneira descrita na cessão de útero, já mencionado.

\section{Limitações da resolução CFM no 2.121/2015}

A resolução vigente (2015) menciona muitos aspectos que envolvem a prática clínica da reprodução assistida. No entanto, algumas limitações ainda podem ser observadas. Em relação aos casais homoafetivos masculinos, não há nenhuma cláusula definindo se ambos podem ser os doadores genéticos. Pode haver mistura de material genético e fertilização do oócito sem paternidade definida? É permitida a transferência de embriões de pais diferentes para o mesmo útero? A resolução é omissa em como proceder nesses casos, mesmo sendo ocorrências comuns nesse público.

A utilização de TRA para pessoas transgênero também não foi abordada em nenhuma resolução, inclusive na vigente. Muitos poderiam se beneficiar da técnica com o objetivo de preservar a fertilidade antes da mudança de sexo. A ASRM se posicionou recentemente favorável a esses casos enfatizando, inclusive, não haver prejuízo para crianças se desenvolverem nessas famílias ${ }^{25}$. Na atualização da resolução de 2015, CFM deveria se posicionar em relação a esse assunto.

Outro aspecto que poderia ter sido um pouco mais elucidado é a questão da doação compartilhada. Da forma como o texto está disposto na resolução, essa opção de tratamento estaria disponível apenas para mulheres onde uma doaria metade de seus oócitos para outra em troca do custeio do tratamento. No entanto, parece que a doação compartilhada de sêmen e oócito entre homossexuais femininos e masculinos seria uma boa opção para esses casos. Tal possibilidade não é mencionada na resolução.

Outra questão não mencionada na resolução vigente é a transferência de citoplasma e a transferência nuclear. Ambas as técnicas têm o mesmo propósito, porém, com processo de micromanipulação diferenciados. A transferência de citoplasma consiste em retirar, através de micromanipulação, parte do citoplasma do oócito de pacientes em idade avançada e substituir por citoplasma retirado de oócito de uma mulher mais jovem. Com isso pretende-se "rejuvenescer" o oócito da paciente mais velha e melhorar as taxas de fertilização e gestação $0^{26}$. Já na transferência nuclear, o procedimento consiste em retirar o núcleo do oócito de uma paciente em idade avançada, e reintroduzi-lo dentro de um oócito anucleado de uma paciente jovem ${ }^{27}$. O procedimento é motivo de polêmica devido ao fato do citoplasma conter material genético proveniente das mitocôndrias. Com isso poderíamos ter um embrião resultante com DNA vindo de três pessoas: do espermatozoide do pai, do núcleo do óvulo da mãe e da mitocôndria do citoplasma da doadora jovem. Os defensores afirmam que o DNA mitocondrial representa uma ínfima parte do DNA total, cerca de $0,1 \%$. Por isso, não haveria maiores problemas e que tal procedimento seria a solução para mulheres em idade avançada. Além disso, esse procedimento já foi utilizado com o objetivo de evitar doenças genéticas relacionadas ao DNA mitocondrial ${ }^{26,27}$. 
Esse procedimento já foi aprovado na Inglaterra, França e no Cazaquistão (18). Devido aos seus resultados positivos, é possível que seja um procedimento cada vez mais utilizado. Por essas questões, é necessário que a próxima resolução do CFM para normas éticas na prática da TRA se posicione em relação ao uso dessas técnicas.

Por fim, ainda que a resolução vigente não tenha previsto alguns desses casos em particular, desde 2013 há uma especificação nesse documento de que qualquer exceção, deve ser reportado ao Conselho Regional de Medicina. Esse adendo foi muito bem colocado, pois não dá margem a diversas interpretações como até então acontecia.

\section{Conclusão}

Como pode ser observado ao longo do texto, a resolução que regulamenta as normas éticas sobre TRA no Brasil sofreu grande modificação desde 1992. Foi observado que a resolução evoluiu em relação aos direitos dos homossexuais, adotou medidas mais permissivas em relação a criopreservação, doação de gametas e embriões e cessão de útero e por fim autorizou alguns procedimentos em TRA como a reprodução post mortem, doação e gestação compartilhada. A resolução, a partir de 2013, ganhou um caráter bastante liberal e inovador estando atualizada com a prática clínica.

Para as próximas atualizações, seria interessante incluir alguns procedimentos em TRA que não foram abordados. Tendo em vista que a resolução é a única forma de regulamentação da matéria no Brasil, é importante que o CFM expresse formalmente o seu posicionamento. Além disso, pequenos outros ajustes, que foram sugeridos ao longo do texto, poderiam ser avaliados enquanto a sua licitude ética e incorporados.

Apesar da importância da resolução na área da reprodução assistida, vale lembrar que ela não tem valor de lei. Isso significa que o não cumprimento de alguma das cláusulas previstas constitui conduta antiética, sendo plausível apenas de punição administrativa pelos Conselhos Federais e Estaduais de Medicina. No entanto, não existe penalidade civil ou penal.

Para finalizar, vale ressaltar que a atualização da resolução que norteia TRA deve ocorrer continuamente para que as normas éticas continuem evoluindo juntamente com o avanço da ciência e da tecnologia. 


\section{Referências}

1. Steptoe PC, Edwards RG. Birth after the reimplantation of a human embryo. Lancet 1978; 12(2):366.

2. Corrêa MCDV. As novas tecnologias reprodutivas: Uma revolução a ser assimilada. Physis 1997; 7(7):6998.

3. Robins TE. Ethical Dilemmas in Fertility Counseling. Fertil Steril 2010; 94(3):1170.

4. Rebar RW. Social and ethical implications of fertility preservation. Fertil Steril 2016; 105(6):1449-1451.

5. Diniz D. Tecnologias reprodutivas, ética e gênero: O debate legislativo brasileiro. Brasília: LetrasLivres; 2000.

6. Brasil. Projetos de lei e outras proposições. Brasilia: Câmara dos Deputados; 2016. [acessado 2016 Out 15]. Disponível em: http://www.camara.gov.br/internet/sileg/

7. Conselho Regional de Medicina (CRM). Resolução CFM no 1.358/1992. Normas éticas para a utilização das técnicas de reprodução assistida. Diário Oficial da União 1992; 19 nov.

8. Conselho Regional de Medicina (CRM). Resolução CFM no 1.957/2010. Normas éticas para a utilização das técnicas de reprodução assistida. Diário Oficial da União 2011; 6 jan.

9. Conselho Regional de Medicina (CRM). Resolução CFM no 2.013/2013. Normas éticas para a utilização das técnicas de reprodução assistida. Diário Oficial da União 2013; 9 maio.

10. Conselho Regional de Medicina (CRM). Resolução CFM no 2.121/2015. Normas éticas para a utilização das técnicas de reprodução assistida. Diário Oficial da União 2015; 24 set.

11. Cellard AA. A pesquisa qualitativa: enfoques epistemológicos e metodológicos. Análise documental. Petrópolis: Vozes; 2008.

12. Reis ARG. A fertilização in vitro no Brasil-A história contada, as estórias. Brasília: Biblioteca do senado federal; 1985.

13. Ethics Committee of the American Society for Reproductive Medicine. Criteria for number of embryos to transfer: a comittee opinion. Fertil Steril 2013; 99(9):44-45.

14. Conselho Regional de Medicina (CRM). Resolução CFM no 1931/2009. Aprova o Código de Ética Médica. Diário Oficial da União 2009; 13 out.

15. Brasil. Constituição da República Federativa do Brasil de 1988. Diário Oficial da União 1988; 5 out.
16. Ethics Committee of the American Society for Reproductive Medicine. Interests, obligations, and rights in gamete donation: a committee opinion. Fertil Steril 2014; 102(3):675-681.

17. Ethics Committee of the American Society for Reproductive Medicine A. Financial compensation of oocyte donors. Fertil Steril 2007; 88(2):305.

18. International Federation of Fertility Societies (IFFS). Mt. Royal: IFFS Surveillance 2013. IFFS; 2013.

19. Brasil. Lei 8.069, de 13 de julho de 1990. Dispõe sobre o Estatuto da Criança e do Adolescente e dá outras providências. Diário Oficial da União 1990; 16 jul

20. Caetano LC, Netto L, Manduca JNdL. Gravidez depois dos 35 anos: uma revisão sistemática da literatura. Revista mineira de enfermagem 2011; 15(4):579-587.

21. Bronson R. Role of spermatozoa in the etiology of miscarriage. Fertil Steril 2015; 105(1):47-48.

22. Romana ICA. Donum Vitae: Carta dos direitos da família. Santa Sé: L’Osservatore Romano; 1983.

23. Ethics Committee of the American Society for Reproductive Medicine. Disposition of abandoned embryos. Fertil Steril 2009; 91:667-6670.

24. Brasil. Lei 10.406, de 10 de janeiro de 2002. Institui o Código Civil. Diário Oficial da União 2002; 11 jan.

25. Ethics Committee of the American Society for Reproductive Medicine. Access to fertility services by transgender persons: an Ethics Committee opinion. Fertil Steril 2015; 104(5):1111-1115.

26. Brenne RCA, Barritt JA, Willadsen S, Cohen J. Mitochondrial DNA heteroplasmy after human ooplasmic transplantation. Fertil Steril 2000; 74(3):573-578.

27. Spikings EC, Alderson J, John JCS. Transmission of mitochondrial DNA following assisted reproduction and nuclear transfer. Human reproduction update 2006; 12(4):401-415.

Artigo apresentado em 08/11/2016

Aprovado em 22/03/2017

Versão final apresentada em 25/03/2017 